\title{
ARTFUL SPACES/SAFE PLACES: A GALLERY PROVOKES VOICES THAT INTERROGATE COMMON NARRATIVES OF LATINO IMMIGRANT CHILDREN
}

\section{CINDY BIXLER BORGMANN AND STACY PEÑALVA}

\section{ABSTRACT}

What do Latino immigrant children's voices say as they are provided a safe community space to be heard and soft clay through which to speak? Through art work, focus groups, gallery exhibitions, and filtering data (Peñalva, 2018) this critical ethnographic research (Madison, 2012; Merriam \& Tissdell, 2016; Wolcott, 2008; Thomas, 1993) exposes the complex political nature of linguistic, cultural, and national negotiations in which Latino children and their families in this study engage daily. This work troubles stereotypic mainstream narratives (Dillard, 2012; Hooks, 1990, 1994; Janks, 2010) and points out the need for strong community/university collaborations to impact the excavation of deeper understandings of people in our neighborhoods. This ethnographic portrait of families, part of a larger study, involved the community director in an urban Spanish speaking church and faculty from literacy education and visual art at IUPUI. In this study children created clay objects called "hanging journals" during a summer program. These clay artworks acted as semiotic mediators (Kress, 2010; Pahl \& Rowsell, 2012; Borgmann \& Berghoff, 2005) for voices of this group-voices which routinely go unheard, or are devalued. In other words, the clay became a container for meaning and was imbued with life stories and memories of the young artists. Using theoretical frameworks from the fields of literacy and art, layered with ethnographic tools of observation, dialogue, reflection, interview, video, and analysis, the volume on these important and complicated voices was turned up to hear buried stories and to interrogate commonly accepted narratives that swirl around Latino immigrants and their families.

This study provides a peek into the authentic narratives of children as they share daily navigation across national, cultural, and language boundaries and shows the power of the arts to communicate across contested spaces - spaces of fear, tension, and resistance. This study embraces the necessity of authentic university/community collaborations as a two-way street to understand and empower Latino youth, to better prepare future teachers as agents of change, and to expose versions of immigrant ways of being and knowing that are misconstrued.

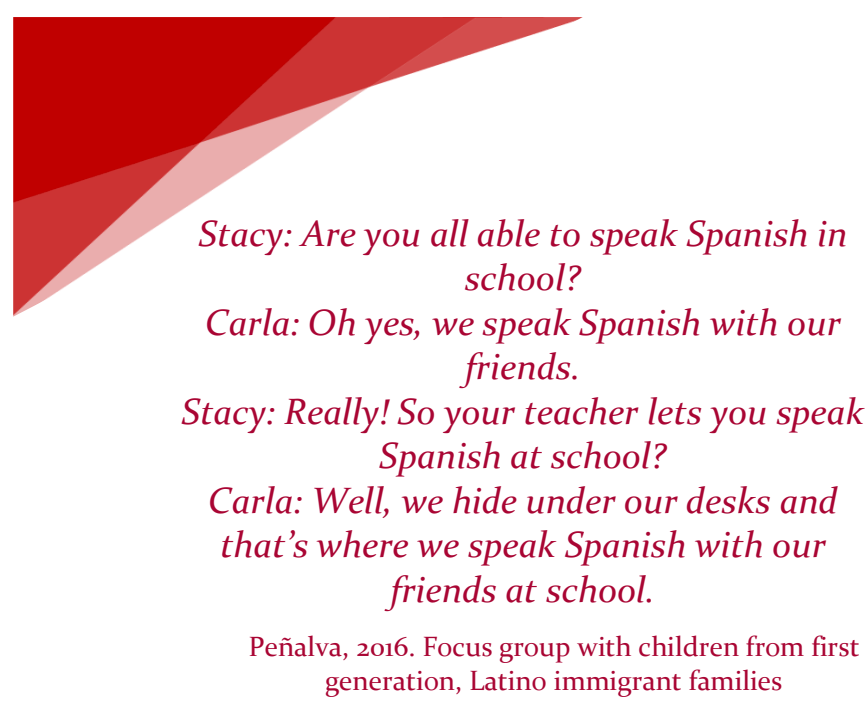

ENGAGE! 2019 Vol. 1 No. 1 https://doi.org/10.1806o/22818 Copyright $(\mathcal{C} 2019$ Author(s). 
Stacy has known Carla since she was born. Her

parents are immigrants from Honduras, and have been members of the church (where the community center site of this research is housed) for many years. While she has worked among the Latino immigrants at this site for decades as a pastor's wife and teacher, this was one of her first conversations with the children at the site as a researcher.

The literal as well as the metaphorical impact of Carla's statement did not go un-noticed. Here the voice of a strong, bilingual and confident little girl was being "shoved under the desk," hidden, devalued, not welcomed in that school room. There was a strong disconnect between the community center and the school; between a place where immigrant voices were heard and welcomed and a place where native language and all the identity and family history wrapped up in that tongue were rendered unimportant and forced to be hidden. Subsequent research grew from this desire to hear and value the voices of immigrant children and their families-what would these voices say if they had a safe place to speak? How could the volume on these voices be turned up to understand their deep undertones, histories and nuances?

\section{SITUATING THE STUDY}

This paper, part of a much larger research study, explores how spaces can be created to truly hear voices of immigrant children and their families. The study strains to hear what those voices are really saying by examining the children's artwork and the voices that flow from that work, and interrogates ways that academia and community spaces can work together to hear, value and learn from those voices.

\section{THE RESEARCHERS}

Stacy

I was born in Pennsylvania and grew up in a monolingual, predominantly white, middle class world. Upon attending college, I met people from other countries who spoke other languages and had much different histories than mine. I married a man from Honduras, and went to live in the mountains outside the capital city of Tegucigalpa for 5 years. There I lived my life as "the other," learning a new language and muddling through an unfamiliar culture. My two oldest sons were born there, and I watched with wonder as they learned two languages simultaneously and navigated the countries and cultures of their birth with apparent ease. This is where my curiosity began regarding the ways that people navigate daily across the borders of language, nations and cultures translingual, transnational, and transcultural.

For the last 30 years I have worked in a church and community center where first generation Latino immigrant families congregate and form bonds, sharing histories, languages and struggles. In recent years I have worked among this group as the pastor's wife and community director but also as a researcher, digging into stories they willingly share and trying to honor their voices-all the while in awe of their resilience and resourcefulness as they carve out a life in this country (Peñalva, Coggin and Medina, 2014; Peñalva, 2016). My stance as an advocate and partner with those who "come to a new awareness of selfhood, looking critically at the social situation in which they find themselves" (Freire, 1970/2009) is unapologetically evident in this research. 
Cindy

I was born in Indianapolis and, like Stacy, grew up in a monolingual, predominantly white, middle class world. As an art teacher I taught in the suburbs of Indianapolis, completed graduate school working with colleagues from different cultures, nations, and languages, and entered higher education at Indiana University Purdue University Indianapolis. For the last 30 years I have taught in the urban teacher preparation program at Herron School of Art and Design working with schools and teachers across the city. Our school now sits where a long history of immigrants once resided and our campus is neighbor to Latino residents. Like many major cities, Indianapolis schools have experienced a rapid increase in immigrant populations, though curricula have not been as quick to change. In my work with urban teachers I have seen the struggle of crossing language barriers in a scripted curriculum and empathize with students and teachers as they negotiate new terrain. Through my research, studying the impact of arts-integrated curricula in general urban classrooms, I have seen the power of the arts in providing equal access to knowledge where high stakes testing, dominant language curricula have denied it to all but the mainstream culture. I have witnessed the transformative power of the aesthetic experience afforded through the arts, to unleash personal voice, nurture agency and empathy, and change dispositions in students and teachers. Teachers have used this newfound agency to push back against test prep, pre-packaged curricula that privilege one way of knowing, and to bring student voice back to their classrooms (Borgmann \& Berghoff, 2013). Art provides an avenue for personal expression, empathy, and meaningful narrative often denied learners outside the dominant language. Providing space in classrooms for a visual language where all can communicate helps break down stereotypic narratives and biases in both learners and teachers.

The arts allow teachers to cross language barriers, to find space in the general curriculum for children's voices, to honor multiple ways of knowing and being, and to provide more equitable and caring learning communities for all. (Borgmann \& Berghoff, 2011, 2013).

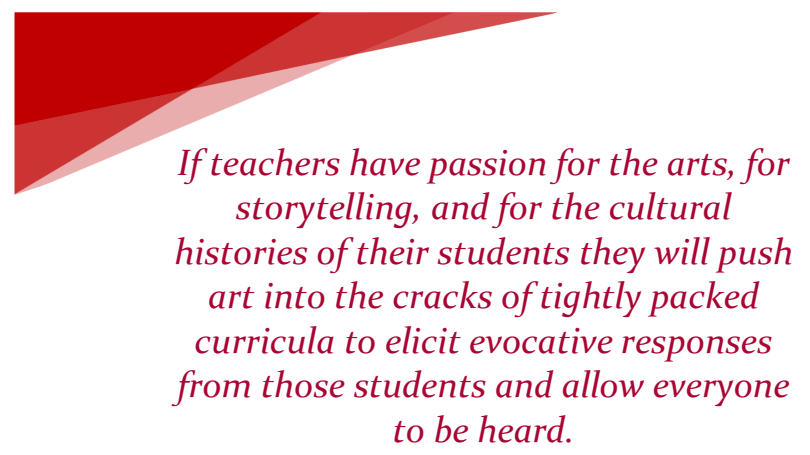

Through this work Stacy, a language arts doctoral student at the time, invited me onto her doctoral committee to join in this study on the voices of Latino youth using art media. On visiting her youth group at the community center it was apparent these children were comfortable in their "habitus" (Bourdieu, 19983/1991 space of the church - at home with the Director. As the gatekeeper of this group, Stacy provided access that would be the envy of any teacher/researcher. Here students spoke openly and candidly of their opinions, faith, and their responses to the day - in English and Spanish. We interpreted the work of Maria Lomas Garza's work, an artist who paints the rich stories and histories of Latino culture, 
and the children painted important objects, food, and traditions from their daily life. As these children painted, defenses were down and the voices flowed in this safe, faith-based community space. Stacy continued curating that safe, artful space using children's clay objects strung together to tell stories of daily life - life as immigrants. These clay objects became "hanging journals" operating as visual text and are the focus of this present manuscript.

\section{THE SITE}

To the west of campus sits an old church, built in 1924 and a longtime home to immigrant families in the city. For 30 years Stacy and her pastor husband have served a dominant Latino population at this site with 150 church members from many different Latin American countries and a community center which provides classes and services for the neighborhood around the building. The church/community center is a place where Latino immigrant families come to share language, faith, and fellowship. They share a similar story in their struggle to arrive at this city and make a life here. They hope for a better future for their children, many who were born here in the U.S., resulting in mixed status families or families where the parent(s) are undocumented and the children are citizens.

This church is an in-between space where English, Spanish and the hybridization (Medina, 2010; Canagarajah, 2013) of the two are routinely heard through the building. It is a place where children eat pizza and play on their phones while parents prepare tamales and laugh in Spanish. A place where the mixing of cultures, languages and national affiliations create a "zone of contact" (Pratt, 1991) allowing and even welcoming the bumping together and jostling around of cultures, languages, ways of doing and knowing. It is an in-between space where these transnavigations -- flowing through available cultures and languages, become common and every day. For example, when the children were shown a picture of food (see photo 1) and asked to talk about it, they noted nothing out of the ordinary. The Mexican crema and typical American macaroni and cheese sit on the shelf side-by-side at a neighborhood store just down the street from the community center as unceremoniously as the children in the church mix their stories from native lands and current residence. This is a powerful narrative, yet has become so embedded into the lives of the people in this "inbetween" space that they do not notice it as conversation-worthy. It just IS.

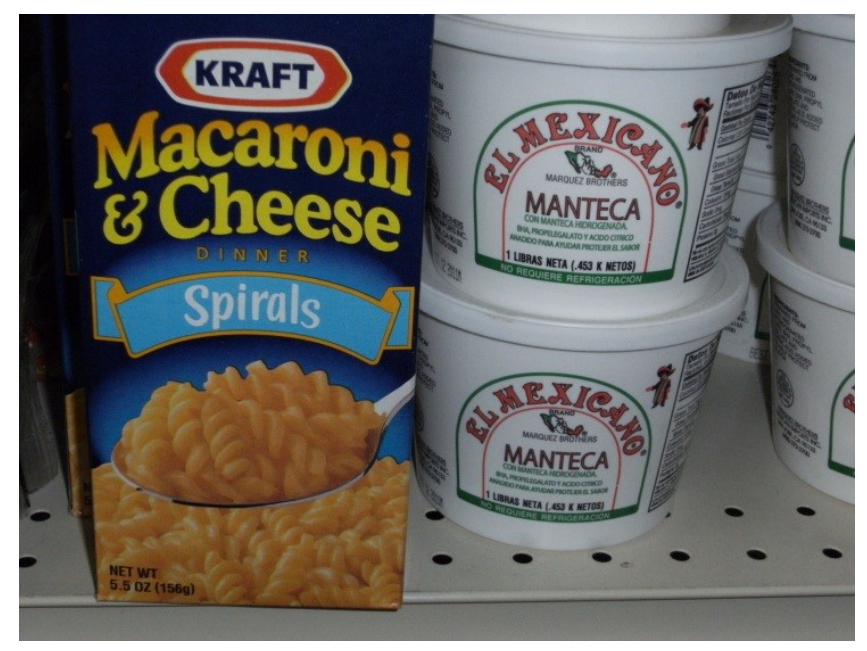

(Photo 1: The ordinary side-by-side nature of transnavigation as seen on a neighborhood store shelf -- a reflection of how immigrant children understand their lives.)

How could spaces be opened to explore the complex choreography of this intricate dance through 
languages, cultures and national identities which seemed to be such a natural way of life for the children? How could the volume on voices at this church/community center be turned up to allow typically non-sanctioned topics to be interrogated freely (Jones, 2004)? Only by genuinely and profoundly hearing these voices could one come to know (Palmer, 1993) and understand this complex group who are often characterized by stereotypical or simplistic narratives.

\section{THE PARTICIPANTS}

The research discussed in this publication is part of a much larger study but due to limited space, we will focus our discussion around data obtained from one child (Maria). However, each of the 20 childrenartists who participated in the original study share certain characteristics with Maria. They are all children from first generation Latino immigrant families. All know the story of their parents' journey to this new land-some are more horrendous than others. Each one is bilingual, with Spanish as their first language. Each child's family is involved in this church and each child attended a summer program at the community center located there. It was during the summer program that the children engaged in an art making project called "hanging journals" that became a focus of this research.

All the children in the annual summer program were between the ages of 6 and 12 during this project. Maria was 8 at the time. When Maria speaks, it is hard to tell that she spoke Spanish exclusively for the first few years of her life, since she speaks English as clearly as any other Li English speaker. Maria was born in the U.S. Her parents are from Mexico, and while her father has permission to live and work in this country, her mother does not. She has two brothers, one older and one younger, who were also born in the U.S. Maria's family is typical of many families at this church. Her parents work long, hard hours. Her father has a painting business. Her mother helps with the business and does other work as it is available. They own a home not far from the church, and are deeply involved in the life of the church. Stacy had known Maria for 4 years at the start of the research since she had participated in many of the programs at the community center. This study using art as a mediator (as a conduit to hear voice) helped to understand and know her in ways not previously imagined.

\section{CRITICAL ETHNOGRAPHIC METHODOLOGY/DATA ANALYSIS}

Ethnography as a research methodology is devoted to describing the ways of life of human kind -in this case, children from immigrant families. Goodall says that "voice is the sound of the ethnographic world being called into being" (Goodall, 2000, p. 139-140 as cited in Madison, 2012. p. 228). In this study, criticality blends with ethnography as the work involves an effort to confront issues of power and injustice through the sharing of voice...

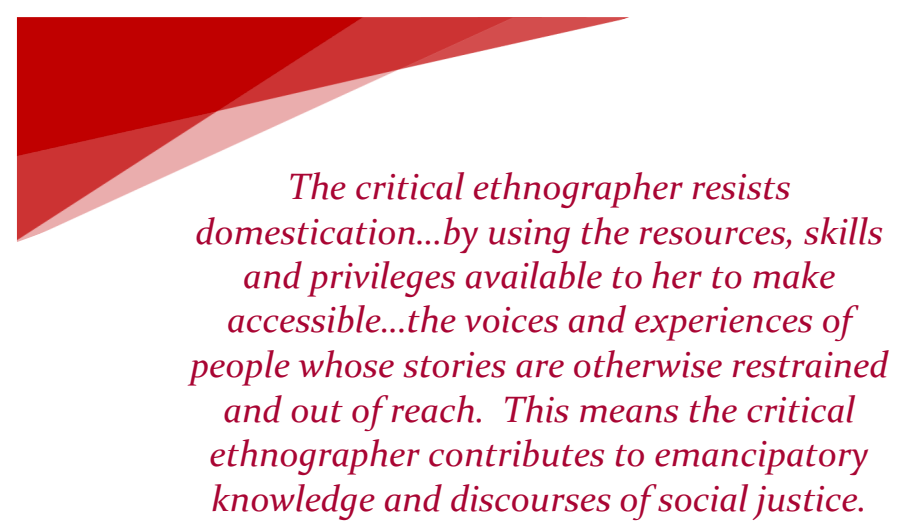

Madison, 2012, p. 6 
During the summer program, the children participated in a curricular activity called "hanging journals." Here they were asked to think about their lives and to remember important events. Next they thought of a way to represent this event by forming clay objects. These objects were hung from sticks decorated with colorful yarn that created a visual story of the child's life -- a text full of storied significance (see photo 2).

Each child was asked to talk about his/her hanging journal with a videographer who created a video with snippets from each interview.

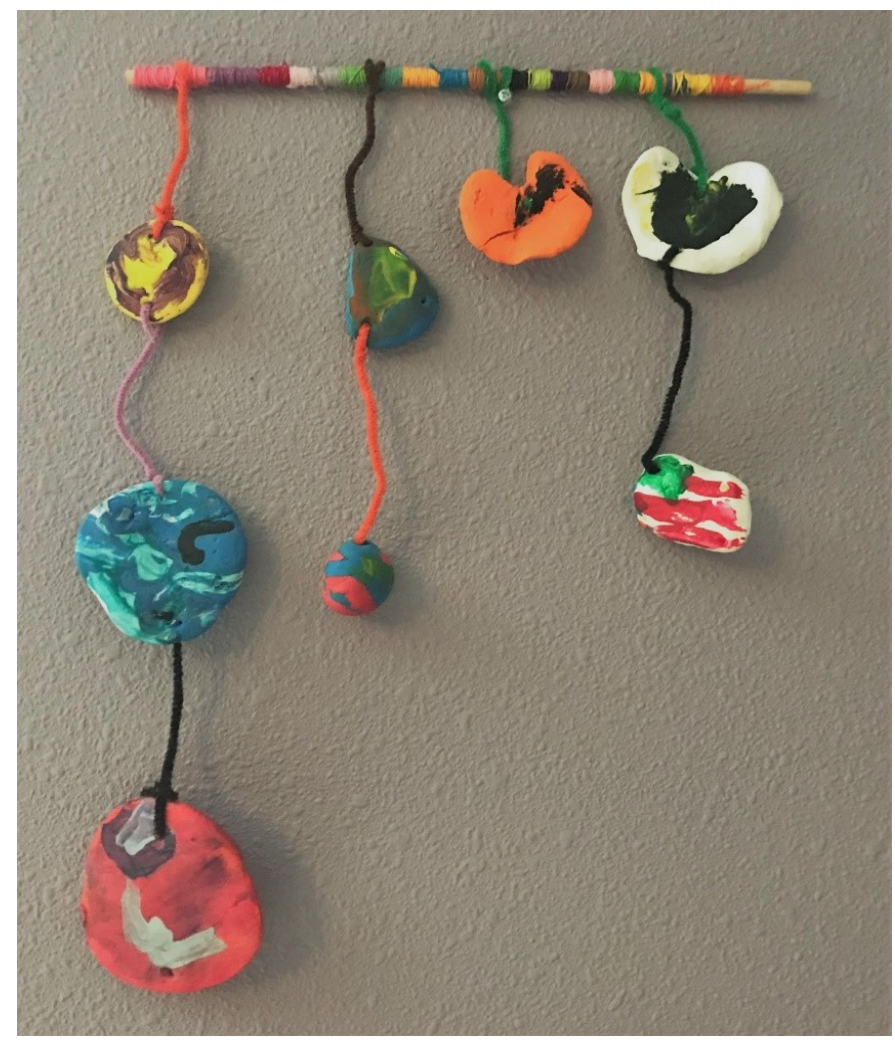

(Photo 2: Maria's hanging journal)

A gallery was created where the journals hung alongside words the child used to talk about that journal (see photo 3). A video monitor in the gallery showed the movie created during the interviews on a loop. The gallery was called "Voices/Voces." It had a grand opening and became a popular space in the church/community center for both the children artists and other visitors.

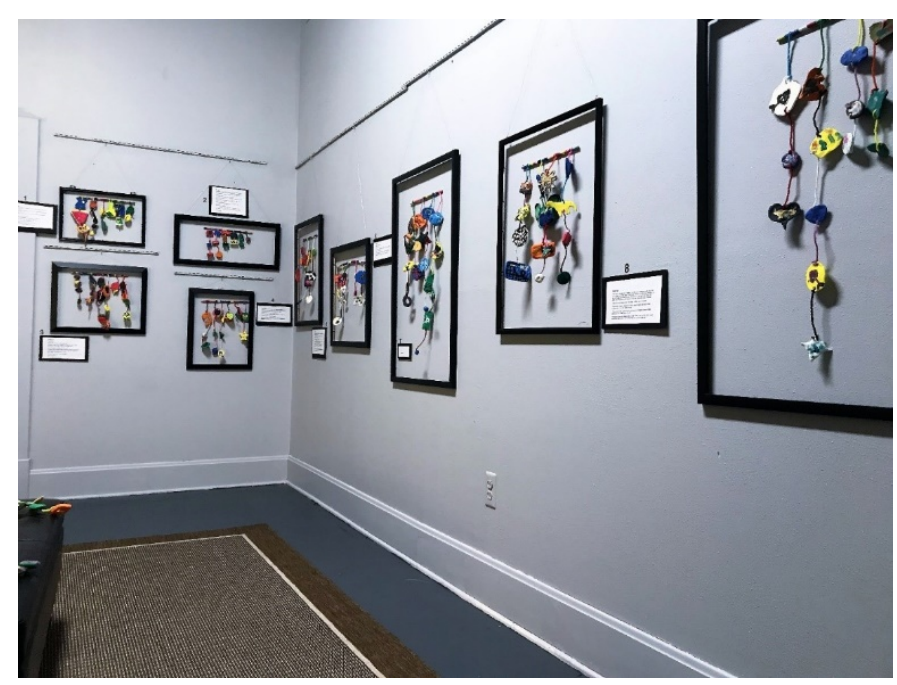

(Photo 3: The Gallery called Voces/Voices located at the church/community center)

A few months after the gallery installation went up, Stacy held a focus group with a dozen of the artists. We met in the gallery and talked about their art and topics that emerged from their hanging journals. Shortly after that, another focus group with 8 of the artists' mothers provided yet another layer of data to understand the deep historical narratives contained in the artwork. Transcribed voices were coded for emerging themes and axial analysis -- examining the data across all the sets collected -- (Merriam, 1998; Cresswell, 2007; Patton, 2002) revealed explanations that interrogated the simple "one story" of immigrant families, providing a peek into what it truly means to live as a child in such a family. 
HEARING MARIA

\section{THE HEART}

Maria chose to put a heart on her hanging journal (see photo 4).

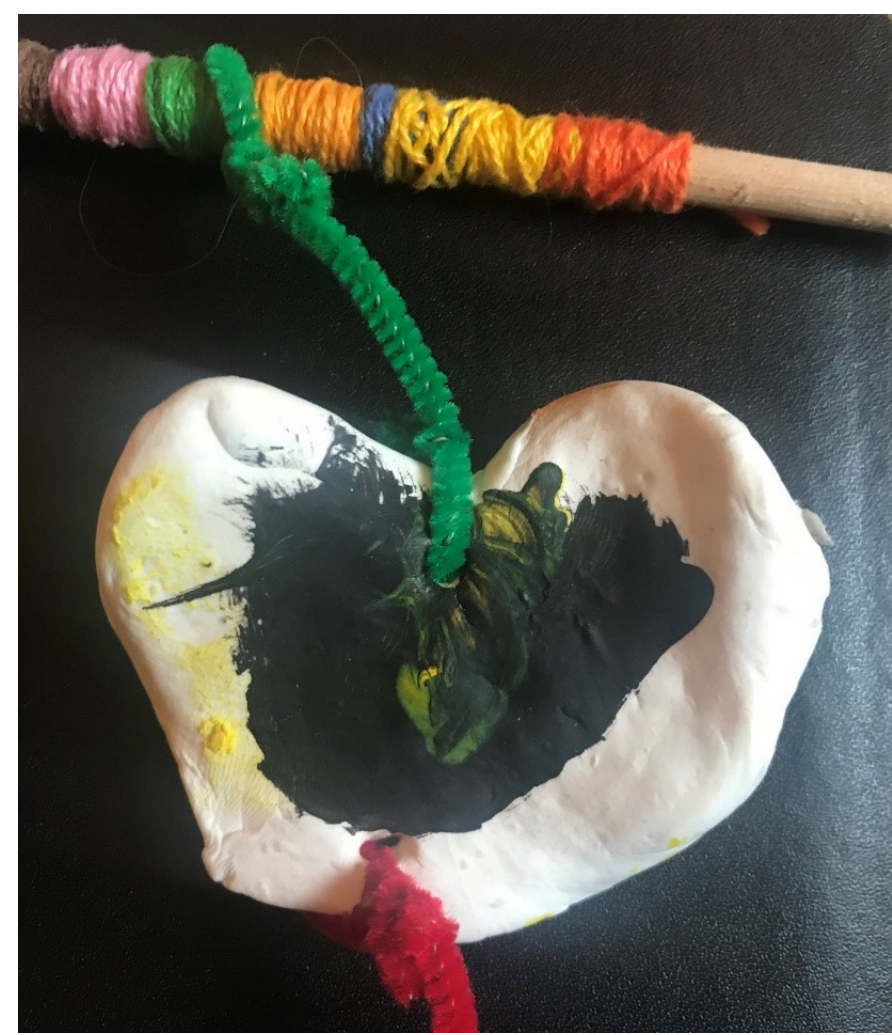

(photo 4: Maria's clay heart)

She briefly told the videographer about this part of her journal:

Maria: I put a heart because my family is always with me.

We might expect this comment from an eight-yearold girl as she talks about her mother -- this feeling of closeness and love. But as Maria's voice continued, other nuances and more obscured narratives seem to peek out from those sweet words. Why did she and many of the other children seem to emphasize this sense of always? Linda and Gabby, for example, also seemed to focus in on the importance of permanence in family love...

Linda: This is my family and I will cherish them forever.

Gabby: And I put three family, and it's important to me 'cause if something happens to my family, it's my family still.

I wondered if I was hearing a barely audible message of family togetherness as a tenuous or fragile condition.

Later, during the artist focus group in the gallery, Maria's artful voice was articulated in deeper ways, as she turned up the volume on the message mediated by her clay heart. Apparently, the heart told of a story deeper than just affection shared by a young girl and her family.

Maria: My mom uses the other side of this (she is wearing a necklace with half a heart) and this reminds me of her when I'm at school. 'Cause I always wear it, but if I wear it inside the shower it will get ruined.

The clay seems to be speaking louder now -- it is actually a model of her necklace, a physical connection between the two -- a way to feel her mother close even when they are apart. Now it becomes clearer why she said the heart meant that her family is always with her.

Later in the artist focus group, Maria uncovered the meaning contained in that little clay heart even further. Listen to the voice of this citizen child from an immigrant family as she and her friends got around to the topic of deportation: 
Maria: We can't go to Mexico. My mom said we are not going to go anywhere. We are just going to stay here until they kick us out of our house. While this may be an unsanctioned topic in many settings, here at this in-between space (Soja, 1996; Gutierrez, 2008) where citizen children live in mixed status households, the topic was not only sanctioned but a daily lived experience. All the children have been touched in one way or another by deportation. Those who have parents without proper documentation take on the life of hiding and fear so common of undocumented people. Maria, a U.S. citizen, hides in her house, close to her mother with whom she shares the heart, in fear that they will be kicked out.

She is not the only child who lives this fear...

Gaby: Yeah, that's what I'm worried about. A couple just came to my house and say you need to go back to where you are from and your kids too. You'd have to live with others, other members. You might have to go to a place where kids don't have parents.

The most terrifying scenario for the children in this group seemed to be the possibility of separation from their parents. They talked openly about the fear of being taken away from parents who could be deported. This fear became clearer and the aching anxiety and love pulsing in the clay heart more profound as Maria's mother spoke at our mother's focus group.

Gracia (Maria's mother): The question you asked, Miss Stacy, about it being a carga (burden or heavy load) that we give our children knowing if we are legal. For me, yes, it was a carga because when she (Maria) listened to things in school, she cried. She would come home crying saying, 'I don't want them to send you to Mexico and with whom will we live?' And I told them not to worry because your dad at least has a permit. If something would happen, if I would not come home, don't go out in the street looking. Just wait for your dad and he will take care of things because one never knows what could happen.

The voice flowing from the mediator -- that clay heart -- became more meaningful after hearing the words and seeing the heart as situated in Maria's lived histories and everyday realities.

Maria: I put a heart because my family is always with me.

The art along with the dialogue around it turned up the volume on the voice of this young girl from an immigrant family. Now we hear her saying that the clay heart presents narratives that swirl around a piece of jewelry she shares with her mother -narratives that speak about fear of separation, of hiding in the house together, of hoping to be together always. As this little girl sits in a classroom each day, wearing her precious half-heart necklace, how many know about her hidden terror, her obscured narratives of potential separation from her family on any given day, her fear about what she might encounter as she arrives home from school?

\section{THE FLAG}

Maria also chose to put an American flag on her hanging journal. Of all the many memories or important events that she could have included on her journal, she chose to craft the flag (see photo 5). In 
fact, many of the children voiced deep connections to the United States. Notice the clay is structured with American stripes colored in red and white but in place of stars is a field of green, the color of the flag of Mexico - a blending of cultures.

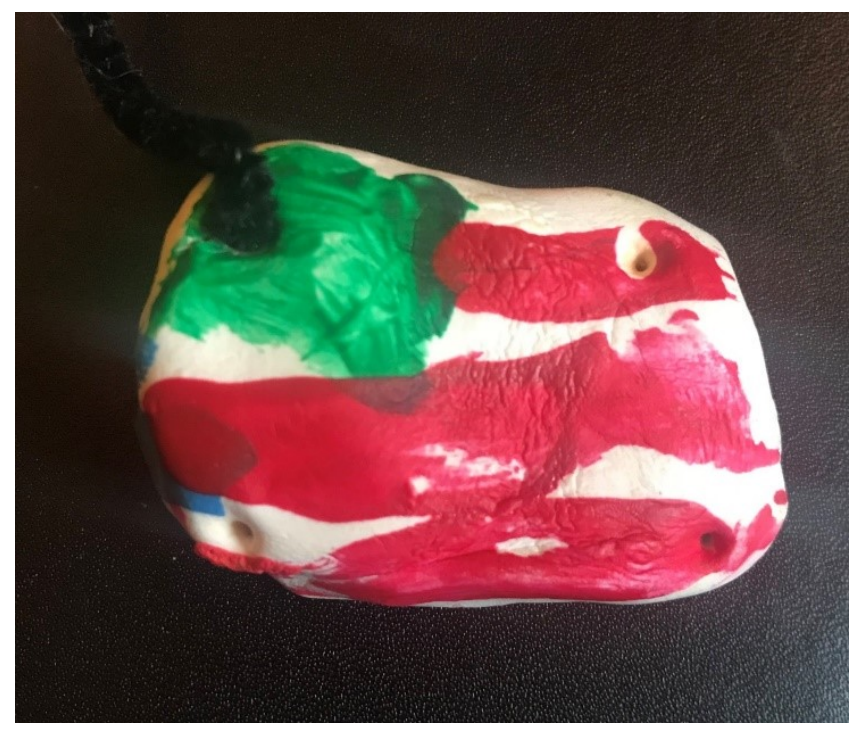

(Photo 5: Maria's flag)

She spoke of her flag:

Maria: This is the flag of the United States.

Every time I go to school in the morning I say the Pledge of Allegiance.

In fact, Maria pledges allegiance to the flag which stands for the same government from which she hides, which might snatch away her home and her family. This citizen-child lives in the world of the undocumented with all the feelings of powerlessness and fear wrapped up in that existence. Does her teacher hear the conflicted voice as she wears a heart that assures connection to her mother, while pledging allegiance to the same country that could rip her mother away? In the everyday-ness of Maria's recitation is a political message that could only be heard as the artful mediator opened up safe spaces at this community center for talk that is often unwelcome or misunderstood in schools (Garcia, 2002). Maria's voice now sounds loud and political -- the outcry of a citizen-child who has put on the fear and powerlessness of her "illegal" parent. It is a voice that grapples with both entitlement and fear. This is a narrative not often acknowledged in the typical immigrant story.

THE T.V.

Maria chose to put a television on her hanging journal to represent this part of her life story (see photo 6). She states...

In this one I tried to draw me watching T.V. with my family. Sometimes I watch movies with my family and it makes me feel good.

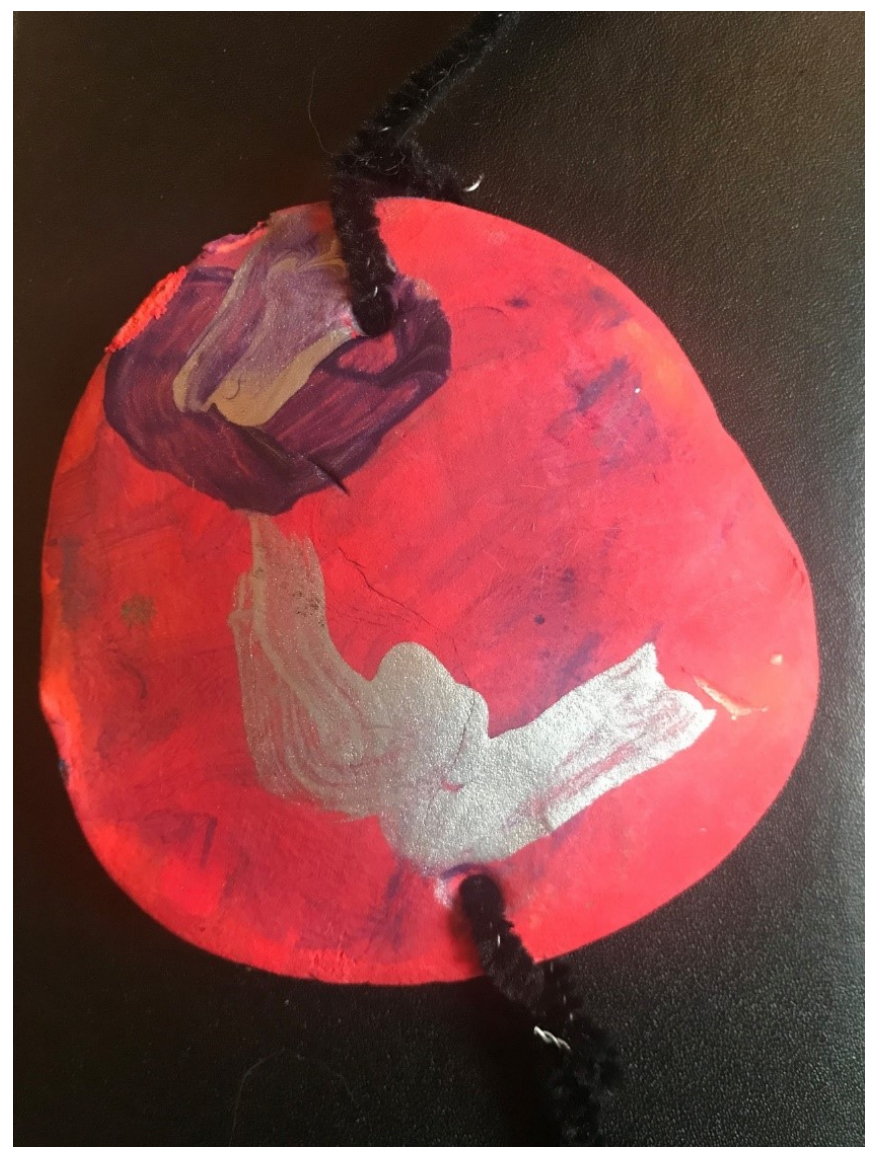

(Photo 6: Maria’s T.V. artwork) 
Her story around family togetherness is contained in this artwork, creating a picture of warm times, gathered around the T.V., watching favorite movies in her home. Her mother's voice from the parent focus group adds complexity to this simple narrative providing deeper insights...

Gracia: For me, I watch cartoons with the children, because they repeat and repeat so that children can learn things, and for me it is easier. I have been here almost 14 years and don't know how to speak English, but it's because I was always watching everything in Spanish, until my husband said, 'No more. We are going to take away all that so you can learn English watching cartoons with the children.' And so now I watch T.V. in English. I cannot speak, because I get nervous and tongue tied, but I understand most of what they are saying. If I put a movie and watch with the children, I can understand 80\%. I have realized that it is a good way to learn English, watching the television with the children in English. And when I say a word wrong, they correct me.

In this new portrait, painted with deeper and more historical colors, Maria and her family sit on the couch to watch T.V. not just for fun times but for learning a language that provides access to the dominant culture and to power (Bourdieu, 1983/1991). Re-interpreting that clay piece, we now hear a story of a mom who has been willing to surrender her place as the one in charge, and become the student. She watches children's programs and learns a new language from her children who have become the patient and capable language instructors. This is the "resistance story" (Whitehead, 2012, p 36) that when told counters stereotypic narratives and positions Latino youth as assets (Cosier, \& Gude, 2012). This story was completely missed in that clay piece, until reinterpreted and shared through dialogue during the parent focus group. As parents spoke together, sharing common stories and engaging in dialogue full of trust and caring with others who share similar narrative, they provided a profound and powerful backdrop to meanings contained in the children's clay artifacts!

This little clay medallion unwrapped a story full of unexpected scenes: a mom watching cartoons together with her children, children patiently helping her to understand the English dialogue, children softly and maybe laughingly correcting mom's mispronunciations, and lots of good feelings and love. This scene is one that makes Maria "feel good."

Maria's hanging journal was tacitly telling this story of family support and caring all along, but the buried and obscured narrative was not uncovered until all the voices were heard and the volume carefully turned up. By considering the data across all available sets (the artifact, the children's stories and the parents' voices), powerful counter-stories could be heard.

\section{THE BORDERLANDS CREATED AT THE}

\section{GALLERY THRESHOLD}

The children in this group live in the borderlands -- linguistically, culturally and geographically -- navigating the choppy waters of their lives as children who have ties to more than one language, historical storyline, and national affiliation (Campano, 2007). But these are not the only kinds of borderlands these children pilot through. Sometimes the children in the research study constructed their 
own borders, and these borders reflected lived stories, real life struggles, and the enactment of agency.

For example, the threshold into the gallery -- a place that contained the life stories of the children molded into clay -- was constructed as a line that was meant to keep some in and some out. The children defined the boundary line at the doorway and acted as the sentries there. Maria and many of the other children understood this borderland, and were clear about who could cross and who could not. Their comments seem to be emblematic of a much larger narrative that examines the notions of knowing and caring (Noddings, 1984) -- things that Maria and her friends wish they had more of at school. They believe the gallery may be the type of place to elicit that love and compassion.

Stacy: Why do you think it's important that other people from outside our group see your work [in the gallery]?

Maria: So that they can see that we worked hard, cause at school let's say someone comes to church from your school and you tell them that you have been working really hard on your art, and they don't believe you, but if they come and you can prove it cause it's in the gallery.

The gallery seemed to be a place where the art was validated -- those who came across the borderlands would be able to believe that you really did work hard. Those who did not come in may not believe that you had worked hard.

Stacy: What would be important for your teacher to know about you that maybe you never had a chance to tell her or she never asked you?
Maria: Like, more stuff about you, 'cause when I go to school I just tell them about my week and I want them to know more about me.

Hector: Sometimes people don't know you ... your teacher could know that you are unique.

Gaby: If my teacher came in here and it was just me and her I would tell her about my life and about my journal and now she can understand what happens in my life and home and at school.

This community space promoted conversation around the need for knowing and caring in the form of teacher action (Noddings, 1984, p. 10) so coveted by the children. One wonders if Maria's teacher realized how desperately this little artist longed to be known in deep and intimate ways. Maria wanted her teacher to know more than simply what she does in her week. Maria goes on to converse with her friends in the gallery, noting the frustrating disconnect that she feels with her teacher.

Maria: One day my teacher was just eating an apple, that's all, just eating the apple. And I said I wanted to tell her something and she was like, "I'm eating right now."

Stacy: Maybe she can't eat and talk at the same time.

Maria: But when we are eating she bothers us! Gaby: Yeah, because they just don't want to hear it -- they say "hold on, I'm busy" but then you look at them just doing nothing and you're like, come on!

While the teacher's voice seems to be considered important and valid, Maria feels like she is being pushed away and that her voice does not matter. 
In this case the powerful teacher demands respect at all times (demanding attention when she speaks and silence when she does not want to listen), while the docile student is expected to comply - here the teacher talks and the students meekly listen (Freire, 1970/2009). Various children in the group used their voice and the notion of the gallery border to express their yearning for a teacher who hears them. They would gladly open the border of the gallery for this teacher and invite her to truly hear their voices.

There is quite a contrast in reaction when the artists were asked what they would say if President Donald Trump came into the gallery -- across that same borderline. Reactions ranged from running away, to lying about the hanging journal to telling him to get out or locking him in the gallery and not letting him out. These citizen children held firm to secure a boundary where powerful forces threatening their families attempted to cross. In fact, Maria had a question for President Trump:

Stacy: Maria, what would you tell Donald

Trump?

Maria: Why are you going to build a wall?

She questioned the construction of a border wall, just as she constructs her own border, trying to keep out a government that she sees as a threat to her family unity.

The children defined and decided who would be welcomed across this border and who would not. Maria and the other children longed for the teachers to cross the border into the gallery, to hear about their journals and truly get to know them -- something that had not been happening in school. On the other hand, they guarded the border from government and power, pushing the President of the United States out and telling him lies.

Stacy: Kenzie, what would you want Donald Trump to know about you.

Kenzie: Nothing!

Gaby: If Donald Trump came in here I would open up the thing and throw him out of the thing.

Camila: I would run away, because one of my friends got deported back to Mexico.

It is the same space, the same border, and yet extremely different decisions and demonstrations of agency at the line. The same space defined by the same border became at once a place of welcome (for teachers) and a place of contention and dispute (for the president).

DISCUSSION: PERSONAL NARRATIVE AS COUNTER DISCOURSE

The arts are forms of communication about things that count (Anderson, et.al., 2010) Anderson \& Milbrandt, 2005, Dewey, 1958/1934). Through the mediated sign of visual imagery artists of all ages shape media into personal expressions that dance around the core of life -- big issues such as identity, power, or place. (Walker, 2001, Robertson \& McDaniel, 2017)

These hanging journals had culturally significant meaning encoded into the bits of clay that told complex stories of their identity. In a classroom where teachers are taught to unwrap these artworks to hear the powerful narratives of all children, the results can be transformative.

Humans construct what they know and who they are through narrative -- or story -- in word, text, 
gesture, visual imagery, or song. As a way of knowing, narratives seek to establish personal truth. Narratives emerge from an individual's reflections on life. As we tell our stories, we organize and re-organize our memory, and construct our own reality (Bruner, 1985). It is not only critical that students have opportunities to create these narratives, but that they have time to reflect on and dialogue with others about these stories.

These Latino children share their fears, struggles, and joys as they work, each with unique families and stories, but a common theme begins to emerge. The cultural histories of separation from border crossing and the threat of deportation or separation from loved ones is a constant fear. Yet, these children build bridges of resilience around the threat that looms close, finding normalcy in this way of life. It is through the voices of children that we see beyond the black and white of immigration. These children are active participants that do not take family responsibility lightly -- they shoulder the burden together.

The Latino children in this study do not see themselves or their families as helpless victims of a political system or as ones who break the law. Their voices offer counter discourses to stereotypic narratives of Latino youth by the mainstream culture (Alarcón, 2014). They are not slow, uneducated, lazy, or disrespectful. They love school, follow the rules, and desperately want to be valued as worthy, respected contributors of their class. They are resourceful, exuberant, and full of agency. And, they have taken on heavy family responsibilities as they navigate through the in-between spaces of different cultures, nations, and languages. Spaces that are further troubled with the social stereotypes of an often-misinformed mainstream culture.

Curricula focused on high stakes testing of the dominant culture privilege one way of being in the world. They create invisible boundaries which leave little room for empowering projects such as these in schools. As O'Loughlin (2009) explains,

Schools are the chief ideological instruments of governments ... and are therefore likely to be held on a tight ideological leash. Teachers are part of the establishment, and any subversive leanings that they might have are typically disciplined through extensive mandated curricular requirements and onerous regulation that appears to be increasingly global in reach. (O'Loughlin, 2009.p. 146)

However, teachers can find gaps in the daily curriculum through which to integrate the arts and support the personal narratives of all students, not just those of the dominant culture. Providing curricular spaces for these personal narratives or counter discourses offers a prime opportunity to break down stereotypes and turn up the volume on all voices. Here O'Loughlin (2009) explains the critical role of the community group:

Such counter discourses need to emerge organically out of community members and must be cultivated from the felt needs of particular groups rather than being handed down from on high. O'Loughlin, 2009. p. 147)

IMPLICATIONS FOR COMMUNITY/ACADEMIC COLLABORATIONS

This community center space, an in-between space with regards to languages, cultures and national 
ties, presents certain affordances when it comes to accessing voices of children from immigrant families.

In the case of Maria and the children in the summer program at the community center, narratives were permitted to unravel out of hanging journal -stories that may not have been expected and that are often not welcome in schools or more formal settings. The arts intersecting with open and safe community space sanctioned topics that may often be absent from discourse in academic settings. These rich stories, full of insights around what it means to be a child in a mixed status Latino immigrant family, are beautiful and powerful but often hidden or buried in the regimentation of school or academia. Through collaborative art making and subsequent dialogue and reflection around artwork, stories spilled from the artists. The stories told of struggle, fear and agency. They told of critical political issues of deportation, family separation, the upside-down picture of family power regarding language, and the real ways that children construct and act as sentries to their personally created borderlands.

There is nothing mindless or disconnected in the art experience. When children form clay into significant shapes from their world a story evolves. The form becomes a visible placeholder for this thought. Each time we encounter that form we bring new information to it, but the form remains to invite us in - the viewer or the artist -- for yet another interpretation. The beauty of art is that it is presentational -- its very form presents the idea providing wide access not bound by language (Eisner, 2002). Another critical part of this study was the dialogue shared while interpreting the clay pieces as conversations that might have otherwise never been spoken flowed from reflecting around the art and the themes it posed.

This dialogue around the stories with which the clay was imbued gave the works meaning that was mediated in such a way that we -- the outsiders -could "get it." Not to be overlooked, however, is the way that the art allowed the children and parent participants to gain deeper understanding of themselves, their conditions and their connections with others of like history. While the project informed us -- the outsiders -- it also provided a consciousness raising (Freire, 1970/2009 experience for those engaged in dialogue around the art, unraveling and reflecting upon their own stories collaboratively. Using visual imagery with clay as well as dialogue allowed for multiple ways of presenting information and making meaning (Serafini, 2014). As the unexpected narratives emerged, a more profound and intimate picture of Maria (and her family and friends) came to light. Suddenly, through her simple artwork, we began to understand her fear of separation from her mother. We felt her patience and admiration for her mom as she worked so hard to learn English. We felt her longing for a teacher who cared enough to know her. We began to relate to her frustration with a government who would, for some reason, want to keep her and others like her out with a wall.

This little girl is a student in any school. She could be a student of any teacher. She sits quietly at her desk, says the Pledge of Allegiance, and comes to school each day with the blessing of her mom and dad. She longs for a teacher and her peers to know and respect her, and strives to understand why anyone 
would want to kick her, or people like her, out of the United States. She is a citizen of the United States, reciting the Pledge of Allegiance, and yet takes on the cloak of an "illegal" hiding in her house until she gets kicked out. Does her teacher know this complex and powerful girl? Does her teacher ask her about her life, her struggles, and her fears? Does her teacher recognize her strengths, gifts and resourcefulness which she lives day to day? Or does her teacher administer high stakes tests and characterize her as a number or a level -- understanding her through the common and stereotypical "one story" of Latino immigrant families in this city, and labeling her rich and diverse historical gifts as a problem to be solved.

As neighborhoods, families and academic entities partner together, we envision a wide open and caring space where identity and authentic story enter the classroom as welcomed ingredients to a community of learning that sees families, histories, languages and cultures as important parts to the recipe for inclusive and equitable learning sites. We envision caring as:

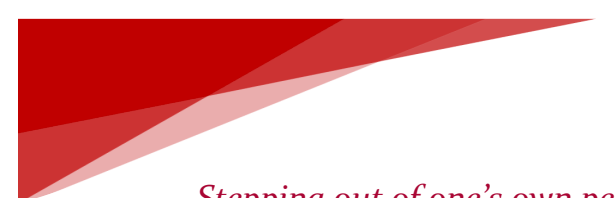

Stepping out of one's own personal frame of reference into another's. When we care we consider the other's point of view.

(Noddings, 1984, p. 24)

We see the nurturing of a "social imagination" -- envisioning possibilities that attend to the justice and equity of all humans (Greene, 2003). We see a place where obscured stories are heard, sanctioned and valued. We see classrooms where children like Maria are seen as capable, full of strengths, and with voices important enough to be valued and heard. We hope to see teachers who open up their arms and hearts and even become learners (Freire, 1980), willing to truly know and appreciate their students. We hope that stories, though hard to talk about and uncomfortable for those of us who have not lived them, are invited in and entertained.

In this work, we have noted the ways that art can open up those spaces, unravel those narratives and create collaborative communities willing to reflect upon topics shared by voices that may have been "shoved under the desk," but are now loud, clear and full of beauty. We have shown here how visual art transcends language and provides all equal access to learning. If teachers have passion for the arts, for storytelling, and for the cultural histories of their students they will push art into the cracks of tightly packed curricula to elicit evocative responses from those students and allow everyone to be heard. These alternative discourses trouble stereotypical narratives and begin a process of understanding of and empathy for "the other." Teachers and community places can collaborate to make sure all children can find a sense of identity and self-respect as they construct personal narratives of possibility. 


\section{REFERENCES}

Alarcón, A. V. M. (2014). Latin American culture: A deconstruction of stereotypes. Studies in Latin American Popular Culture. 32: 72-96

Anderson, T. \& Milbrandt, M. (2008). Art for life: Authentic instruction in art. New York: McGraw Hill.

Borgmann, C. \& Berghoff, B. (2013). Social imagination: Supporting good teaching in tough times. In K. Tavin, \& C. Ballentine-Morris (Eds.), Stand(ing) up for change: Voices of arts educators. Reston, Virginia: National Art Education Association.

Borgmann, C., Berghoff, B. \& Parr, C. (2005). Arts together: Steps toward transformative teacher education. Reston, Virginia: National Art Education Association.

Borgmann, C. \& Berghoff, B. (2011). The arts step up. In Albers, P. (ed) Literacy and the arts, multimodality, and new literacies: Perspectives in research and practice from the commission on arts and literacy. National Council of Teachers of English.

Bourdieu, P. (1983/1991) Language and symbolic power. Cambridge, MA: Harvard University Press.

Bruner, J. (1985). Narrative and paradigmatic modes of thought, in The Eighty-Fourth Yearbook of the National Society for the Study of Education. Part II Chicago: National Society for the Study of Education.

Campano, G. (2007) Immigrant students and literacy: Reading, writing and remembering. New York: Teachers College Press.
Canagarajah, S. (2013). Translingual practice: Global Englishes and cosmopolitan relations. New York: Routledge.

Cosier, K. \& Gude, O. (2012). Community curriculum matters. In K. Hutzel, F. M. C. Bastos, \& K. Cosier (Eds.) Transforming city schools through art: Approaches to meaningful K-12 learning (pp.34-42). New York: Columbia Teachers College Press.

Cresswell, J. (2007). Qualitative inquiry and research design: Choosing among five approaches. Thousand Oaks, CA: Sage Publications.

Dewey, J. (1958/1934). Art as experience. New York, Bantam Books.

Dillard, C. (2012). Learning to (Re)member the things we've learned to forget. New York: Peter Lange.

Freire, P. (1970/2009). Pedagogy of the oppressed. York, London: Continuum Publishing Group.

Garcia, E. (2002). Foreword. In D.F. Brown, Becoming a successful urban teacher. Portsmounth, New Hampshire: Heineman.

Greene, M. (2003). Lecture given at the National Educators Workshop Summer Session. Lincoln Center Institute for the Arts in Education, July, New York.

Gutierrez, K. (2008). Developing a sociocritical literacy in the third space. Reading Research Quarterly 43(2), 148-164.

Hooks, b. (1994). Teaching to transgress: Education as the practice of freedom. New York: Taylor \& Francis Group.

Janks, H. (2010). Literacy and Power. New York: Routledge. 
Jones, S. (2004). Living poverty and literacy learning:

Sanctioning topics of students' lives. Language Arts. 81(6). July, 2004.

Kress, G. (2010). Multimodality: A social semiotic approach to contemporary communication. London, New York: Routledge.

Madison, S. (2012). Critical ethnography: Method, ethics and performance. Los Angeles, California: Sage.

Medina, C. (2010). Reading across communities in biliteracy practices: Examining translocal Discourses and cultural flows in literature discussions. Reading Research Quarterly. 45(1), 40-6o.

Merriam, S. (1998). Qualitative research and case study applications in education. San Francisco, CA: Jossey-Bass.

Merriam, S. \& Tissdell, E. (2016). Qualitative research. San Francisco: Jossey-Bass.

Noddings, N. (1984). Caring: A feminine approach to ethics and moral education. Los Angeles: University of California Press.

O'Loughlin, M. (2009). The subject of childhood. New York: Peter Lang.

Pahl, K. \& Rowsell, J. (2010). Artifactual literacies: Every object tells a story. New York: Teachers College Press.

Patton, M. (2002). Qualitative research E evaluation methods. Thousand Oaks, CA: Sage Publications.

Peñalva, S. (2018). Voices from the gallery: Exploring the translingual, transcultural, and transnational navigations of Latino immigrant families in the
United States. [Dissertation] Ann Arbor, MI: ProQuest LLC.

Peñalva, S. (2016). An ethnographic portrait of translingual/transcultural navigation among immigrant children and youth: Voices during Sunday school at a Latino church. Journal of Multilingual and Multicultural Development.

Peñalva, S., Coggin L., Medina, C. (2014). Examining transcultural spiritual literacies among Latino children through arefactual literacies.

Diaspora, Indigenous and Minority Education: Studies of Migration, Integration Equity and Cultural Survival. 8(2), pp. 92-107.

Pratt, S. (1991). Arts of the contact zone. Profession, 91, 33-40.

Robertson, J. \& McDaniel, C. (2017). Themes of contemporary art: Art after 1980. NY: Oxford Press.

Serafini, F. (2014). Reading the visual: An introduction to teaching multimodal literacy. New York: Teachers College Press.

Soja, E.W. (1996). Thirdspace: Journeys to Los Angeles And other real-and-imagined places. Malden: MA: Blackwell Publishing.

Thomas, J. (1993). Doing critical ethnography. Qualitative Research Methods Series, Vol. 26. Newberry Park, CA: Sage.

Walker, S. (2001). Teaching meaning in art making. Worcester, Massachusetts: Davis Publications Whitehead, J. (2012). Counternarratives: Considering urban students' voices in art education. In K. Hutzel, F. M. C. Bastos, \& K. Cosier (Eds.) Transforming city schools through art: Approaches to meaningful K-12 learning (pp.34- 
42). New York: Columbia Teachers College

Press. 